\title{
A Comparative Framework: How Broadly Applicable is a "Rigorous" Critical Junctures Framework?
}

John Hogan

Technological University Dublin, john.hogan@tudublin.ie

David Doyle

School of Law and Government, DCU

Follow this and additional works at: https://arrow.tudublin.ie/buschmarart

Part of the Business Commons

\section{Recommended Citation}

Hogan, J., Doyle, D.: A Comparative Framework: How Broadly Applicable is a "Rigorous" Critical Junctures Framework? Acta Politica, Vol. 44, No. 2, pp. 211-240.

This Article is brought to you for free and open access by the School of Marketing at ARROW@TU Dublin. It has been accepted for inclusion in Articles by an authorized administrator of ARROW@TU Dublin. For more information, please contact arrow.admin@tudublin.ie, aisling.coyne@tudublin.ie,gerard.connolly@tudublin.ie. Funder: Irish Research Council for the Humanities and Social Sciences 


\section{A Comparative Framework: How broadly applicable is a "rigorous" critical junctures framework?}

\begin{tabular}{|l|l}
\hline John Hogan, & David Doyle, \\
Office 3-062 & School of Law and Government, \\
Dublin Institute of Technology, & Dublin City University, \\
Aungier Street, & Glasnevin, \\
Dublin 2, & Dublin 9, \\
Ireland & Ireland \\
\hline
\end{tabular}




\title{
A Comparative Framework: How broadly applicable is a "rigorous" critical junctures framework?
}

\begin{abstract}
The paper tests Hogan and Doyle's $(2007 ; 2008)$ framework for examining critical junctures. This framework sought to incorporate the concept of ideational change in understanding critical junctures. Until its development, frameworks utilised in identifying critical junctures were subjective, seeking only to identify crisis, and subsequent policy changes, arguing that one invariably led to the other, as both occurred around the same time. Hogan and Doyle $(2007 ; 2008)$ hypothesised ideational change as an intermediating variable in their framework, determining if, and when, a crisis leads to radical policy change. Here we test this framework on cases similar to, but different from, those employed in developing the exemplar. This will enable us determine whether the framework's relegation of ideational change to a condition of crisis holds, or, if ideational change has more importance than is ascribed to it by this framework. This will also enable us determined if the framework itself is robust, and fit for the purposes it was designed to perform indentifying the nature of policy change.
\end{abstract}

\section{Introduction}


For historical institutionalists (Pierson, 2000; Steinmo, 1989) crises are often regarded as the starting points for change. Scholarly interpretations of institutional change have seen the past divided into long periods of normalcy, interrupted by critical junctures. However, until recently, critical junctures, 'a concept needed in underpinning the analyses of temporal processes, have received limited discussion' (Pierson, 2004: 5-6). This was part of an overall absence of tools for making sense of institutional change (Thelen, 1999: 388). Of late, historical institutionalism has moved away from the concept of critical junctures, in search of new ways of demonstrating how institutions are remade (Pierson, 2004; Streeck and Thelen, 2005). This left the critical junctures concept languishing in a conceptual cul-de-sac. Capoccia and Kelemen (2007: 342) pointed to an overall absence of methodological/conceptual rigour in our understanding of critical junctures.

Earlier scholars, such as Collier and Collier (1991), examined critical junctures by means of unwieldy frameworks, or in the case of Fearon $(1991$; 1996) counterfactual analysis. Hogan $(2005 ; 2006)$ sought to develop frameworks with greater rigour. But, all their efforts involved narrow, in many instances case specific, criteria, along with largely arbitrary standards. Macrohistorical analysts developed frameworks suitable for their own subject matters, but ill suited to studies of critical junctures in other fields (Capoccia and Kelemen, 2007: 342).

To correct for these weaknesses, Hogan and Doyle (2007; 2008) developed a detailed, three-stage, critical juncture framework, they claim is capable of explaining why certain crises lead to critical junctures in policies, whereas others do not. Their underling hypothesis is a critical juncture in policy consists of: crisis, ideational change (extant ideational collapse and new ideational consolidation), and radical policy change. The framework is an attempt to rectify what Capoccia and Kelemen (2007: 343) call the 'paucity of conceptual instruments available to define, study, and compare critical junctures.' Hogan and Doyle (2007; 2008) argue that crisis is a necessary, but insufficient, condition for a paradigm shift in policy. A crisis not followed by ideational change will only result in a first or second order policy change, whereas a crisis followed by ideational change will witness a third-order change/paradigm shift in policy, which combined constitutes a critical juncture. Ideational change therefore, is the "differentiating factor" between a crisis that leads to a paradigm shift in policy (critical juncture) and one that leads to less significant policy change (Hogan and Doyle, 2007; 2008).

We wish to investigate if ideational change is an integral component of critical junctures, and if the overall framework developed by Hogan and Doyle $(2007 ; 2008)$ is capable of identifying and explaining various degrees of policy change. Laudable as including endogenous factors (ideational change) is in critical junctures, doing so in the manner set out in the framework relegates ideational change to an adjunct of crisis. A framework such as this ignores the fact that even if its objective conditions are not met, within the historical institutionalist tradition actors' path dependent expectations of economic performance might be such that a crisis could still constitute a critical juncture. Such a finding would relegate the importance of ideational change to something less than a decisive variable in our understanding of critical junctures, while simultaneously relegating the significance of the framework's objective criteria for identifying economic crisis as well. Through our detailed comparative case studies we show that a quantifiable 
macro-economic crisis is not a necessary precondition for a paradigm shift in macroeconomic policy to occur. In fact, we contend that the perception of crisis, identified through qualitative observables, as opposed to its verifiable identification through quantitative observables, can be crucial in influencing the trajectory of policy formulation.

\section{Section 1: Our Understandings of Critical Junctures}

For historical institutionalism the focus is on choices made early in the history of a polity. These choices will have a persistent influence (Peters, 1999: 210). Historical institutionalism is effective at explaining what happens, and in weaving a narrative that captures a good deal of the reality of history. Choices made at time $\mathrm{T}$ influence choices at time $\mathrm{T}+1$ (Berman, 1998: 380). However, explaining change has been problematic. 'Traditionally, students of institutional change focused on the importance of crisis, situations of large-scale public dissatisfaction or even fear stemming from an unusual degree of social unrest and/or threats to national security' (Cortell and Peterson, 1999: 184). Wars, revolutions, coup d'état, changing balance of power, demographic changes, and social movements were regarded as critical junctures, producing overwhelming mandates for policy and or/structural change. Such unanticipated events tended to discredit existing institutions and policies, consequently triggering the change (Tilly, 1975).

Critical junctures are seen as resulting in the adoption of a particular institutional arrangement from amongst alternatives (Mahoney, 2000: 512). Thereafter, a particular developmental pathway is established funnelling units in a specific direction, and is effectively fixed (Mahoney, 2003: 53; Pierson and Skocpol, 2002: 9). Thus, critical junctures set the tone for what comes in their wake.

However, there are cases in which institutions change in unexpected ways, and the approach appears at a loss to explain them. Sometimes there are no wars, or other great events, such as those listed above, that can be held to account for dramatic policy and/or structural changes. 'This is the weakest and most difficult point in institutional analysis' (Rothstein, 1996: 153). Thus, the idea that wars, or revolutions, can be regarded as critical junctures when it suits is too simplistic, reducing the concept to a catchall solution to be employed when situations warrant. This raises all sorts of questions as to what exactly is a critical juncture, and how do we define a critical juncture?

For some authors the duration of a critical juncture can be very brief, while for others it can mark an extended period of reorientation (Mahoney 2001). Collier and Collier (1991) developed a critical junctures framework for examining national development in Latin America. Their definition implied that institutional innovation occurs over a long timeframe (Thelen, 2004: 215). Analyzing the liberalization of Central America, Mahoney (2001) found some critical junctures lasting decades, while their after effects had shorter duration. However, electoral landslides are also regarded as critical junctures, as they produce strong mandates for policy change (Garrett and Lange, 1995: 628). Contextualised by the 1934 Reciprocal Trade Agreements Act, Haggard (1988: 91) argued that economic depressions lead to a questioning of extant institutions, and subsequent changes in polices. Hogan and Doyle's $(2007 ; 2008)$ framework fell into 
the latter camp, in that it argued that critical junctures were swift events. However, their framework differed from traditional historical institutionalist approaches in that it incorporated ideational change and policy change within the critical juncture concept, rather than treating critical junctures and subsequent ideational and policy changes as separate events. In this framework crisis are just one part of a critical juncture, and on their own are insufficient to constitute a critical juncture.

Clearly, the concept of critical junctures has been used by various scholars in addressing a wide range of issues. All seem to agree that critical junctures 'suggest the importance of formative moments for institutions and organisations' (Pierson, 1993: 602). The concept is seen as a handy tool for linking a sequence of events. However, the absence of a standard set of criteria for identifying critical junctures has been a weakness in the concept. Thus, the ability to readily identify critical junctures, as is clamed by Hogan and Doyle's $(2007$; 2008) framework, should mark a significant advance for the concept.

\section{Section 2: The Countries Selected for Examination}

To test Hogan and Doyle framework $(2007 ; 2008)$ we employ the same case selection criteria they used of "most similar" and "most different." Based upon their requirement of "most similar" we select our cases from states that have been stable democracies since the first half of the twentieth century, and were founding members of the Organisation for Economic Cooperation and Development (OECD). These conditions tied together the principles of representative democracy and free market economy. Employing their criteria of "most different" we utilized Lijphart's (1999) categories of majoritarian and consensual democracies in our case selection. This category permits us control for varying institutional arrangements. Employing this method of case selection, we are trying to ensure that the cases examined here, though not identical, are in many ways comparable.

As a result of the above criteria, and similar to Hogan and Doyle's (2007; 2008) papers, cases from Ireland and Sweden will be examined. Both countries are small longstanding democracies, and constitute advanced capitalist states. Despite their similarities, in the periods in which we examine them, their economic performance was very different. Sweden was a prosperous welfare orientated state during much of the latter half of the $20^{\text {th }}$ century, while Ireland struggled to achieve sustained economic expansion. Nevertheless, their similarities ensure the contexts of analysis are analytically equivalent, to a significant degree, while their differences place the 'parallel processes of change in sharp relief' (Collier, 1997: 40). Thus, the framework itself will also be tested in a similar, but also different, environment to that in which it was previously scrutinized.

\section{Section 3: Framework to be Tested}

Hogan and Doyle's $(2007 ; 2008)$ three stage framework is relatively simple. A major crisis will cause agents to question the efficacy of the ideas underlying existing policy, resulting in the collapse of these ideas. In response, change agents will propose different ideas to replace the failing ideas. The ensuing period of ideational contestation will result in either change agents consolidating around a replacement set of ideas, or, in the absence 
of new ideational consolidation continuance with extant failing ideas. Should failing ideas endure, these will continue to inform institutional arrangements, and policy will only change marginally, or not at all. However, if, in the wake of ideational collapse, change agents consolidate around new ideas, these will replace the failing ideas and significant policy change will follow. The overall result will be a critical juncture. So, for there to be a critical juncture in macroeconomic policy there must be a crisis, ideational change (extant ideational collapse + new ideational consolidation), and a radical policy change. To identify each of these elements, a range of observable implications (or indicators) must be satisfied.

To identify a macroeconomic crisis, the original framework presented ten observable implications. Three of these were quantitative in nature, with the remainder qualitative. However, the value of the quantitative observables is questionable, as they seem somewhat arbitrary in nature. The qualitative observables seem somewhat stronger, but Hogan and Doyle $(2007 ; 2008)$ do not appear to use any coding protocols. In light of these weaknesses in the original framework we add another seven quantitative observables to give a further layer of thoroughness to the examination of economic data. In terms of coding the qualitative observables we simply conducted word searches for "crisis", something rudimentary, but which Hogan and Doyle $(2007 ; 2008)$ did not do.

Nevertheless, we still recognise that identifying a macro-economic crisis requires a mix of subjective and objective deliberations (Pei and Adesnik, 2000: 139). As a result, we utilise a total of 17 observable implications in our investigation of crisis. These accept that a macro-economic crisis constitutes a severe economic low point (See Appendix A for all observables). Multiple observables raise the question of how many should point to an empirical-theoretical fit to indicate economic crisis. We argue that at least two thirds of all observables, for which there are findings, should point to economic crisis.

While regarding crises as important to critical junctures, the framework was built around the recognition that ideational change is crucial. A crisis leads to a questioning of extant policies due to their failure to correct the situation. Ideas will present a range of subsequent policy choices in light of crisis. Hogan and Doyle (2007; 2008) contend that that significant policy change is dependent upon change agents (political and policy entrepreneurs) consolidating around a set of new ideas that will determine the path subsequent policy takes. Their belief in the role of ideas in policy change is akin to that of Blyth (2002) and Golob (2003). However, their identification of the role of various types of change agents, and the integration of the concepts of extant ideational collapse and new ideational consolidation from Legro (2000), marks a deeper understanding of where new ideas bubble up from, and how they become consolidated, in the event of crisis.

In this manner the framework locates ideational change as the intermediating factor between crisis and policy change. For a crisis to result in a radical policy change there had to be ideational change. The original framework set out seven observable implications with which to identify ideational change. We keep these, differentiating them into those for identifying extant ideational collapse (first five); and those for identifying new idea consolidation (latter two) (Appendix B).

Extant policies are no longer secure once their underlying ideas have been undermined. Once the ideas policies are based upon have been widely questioned the 
issue is simply will policies change, and if so, to what extent. To identify the nature of policy change, the framework utilised Hall's (1993: 291) concepts of first, second and third order change. The observables, based around these orders of policy change, enable the easy identification, and differentiation, of normal, and fundamental, shifts in a country's macro-economic policies. In this case, we keep the same observables as in the original framework (Appendix C). The framework predicts that in the absence of ideational change policy change will be either first or second order, but never the third order. However, the framework also predicted that confirmed ideational change (new ideas supported by a wide range of change agents, led by a political entrepreneur) leads to third order policy change - a new set of policies coming into force.

This three stage framework presents a range of "objective" conditions that must be met for there to be a critical juncture. These constitute the framework's supposedly independent, but in reality also dependent, variables. They are dependent in the sense that they must occur in sequence. Before ideational change can occur there must be an identifiable crisis. However, the range of observable selected by Hogan and Doyle (2007; 2008) to identify economic crisis are questionable. The level of national debt is not ideal, as the rate of change in national debt would be better, and the observables based on inflation and interest rates seem largely arbitrary. Before radical policy change can occur, there must be both a crisis and ideational change (again based on another set of observable implications). Ideational change is presented in the framework as the intermediating variable between crisis and policy change. A crisis not followed by ideational change is regarded as insufficient to result in a third order change in policy, and consequently a critical juncture. This raises all sorts of questions as to what would happen if ideational change occurred in the absence of any definable crisis, or, for that matter, if a dramatic policy change took place in the absence of ideational change.

A framework, such as this, ignores the fact that even if its objective conditions are not met, within the historical institutionalist tradition, actors' path dependent expectations of economic performance might be such that a crisis could still constitute a critical juncture. Such a finding would relegate the importance of ideational change to something less than a decisive variable in our understanding of critical junctures, while simultaneously relegating the significance of the framework's objective criteria for identifying economic crisis as well. Here we will test the framework's supposed robustness, the clarity of its "objective" criteria, and its overall capacity to identify and explain policy change.

\section{Section 4: The Identification of Macro-economic Crisis}

\section{Ireland $1986-1987$}

By 1987 the Irish economy was locked in a vicious circle of stagnation, rising taxes, and rocketing debt. There was growing recognition amongst most sections of the community that things could not go on as they had, otherwise the economy would collapse. As can be seen from Figure 1 unemployment was close to 20 per cent by 1987. The numbers at work had been in decline since the late 1970s, falling from a peak of 1,145,000 in 1979 to 1,095,100 by 1986 (Leddin and Walsh, 1998: 320). On the positive side, inflation had been declining since the early 1980s, and interest rates, which had been very high at the start of the decade, were also falling, but more slowly. 


\section{FIGURE 1 HERE}

In terms of growth, the Irish economy performed poorly. GDP growth, and GDP per capita growth was stagnant throughout much of the early 1980s (Figure 2). In 1986 both of these measures shrank, an indictment of a poorly performing economy. GDP growth averaged over five years was only 2 per cent. As can also been seen in Figure 2, GNI per capita growth dropped dramatically during the first half of the 1980s, with a low of 1.6 per cent in 1986.

\section{FIGURE 2 HERE}

The debt/GDP ratio exceeded 100 per cent in 1984 (Figure 3), before peaking at over 124 per in 1987. In that period the debt/GDP ratio rose at an average of 4 per cent per annum. In real terms the national debt jumped from just over $€ 10$ billion in 1980 to over $€ 30$ billion by $1987 .{ }^{1}$ At the same time, imports and exports slumped, this reflected in the declining in trade openness. By 1987 it was clear the level of activity in the Irish economy was decreasing.

\section{FIGURE 3 HERE}

We can see from Figure 4 that there was great volatility in relation to FDI. A series of dramatic peaks and troughs mark the variations in FDI inflow throughout the early 1980s. At the same time, the overall change in FDI inwards stock was miniscule. Thus, there was a general stagnation in overall FDI, which continued until economic recovery began in the early 1990s. Gross capital formation (as a percentage of GDP) gradually diminished during the mid 1980s, falling below 20 per cent by 1983. It was only in 1990 that the rate of gross capital formation again exceeded 20 per cent.

\section{FIGURE 4 HERE}

There was unanimity in the domestic and foreign media concerning the economy. The Irish Times used the term 'battered' to describe the economy in February $1987,{ }^{2}$ while, according to the Irish Independent, manufacturing industry was in serious crisis, with one in six jobs disappearing between 1980 and 1987 . $^{3}$ The Economist pointed out that 'the people of Ireland were deeply in debt to the outside world, three times as much per head as Mexico. ${ }^{4}$ During the long recession of the 1980s 'the government borrowed vast sums, and spent them on welfare services that could be sustained only by more borrowing. ${ }^{5}$ Thus, began a vicious circle of indebtedness. The Irish Times noted that some economic commentators were advocating debt repudiation. ${ }^{6}$ Overall, the general consensus in the newspapers was one of stagnation and crisis. ${ }^{7}$

Economists delivered severe criticisms of both policy and performance. Bacon et al., (1986: 1), writing for the Economic and Social Research Institute (ESRI), commented that 'the first half of the decade of the 1980s, taken as a whole, was a period of appalling economic performance.' Kennedy and Conniffe (1986: 288) observed that 'it is difficult to avoid the conclusion that Irish economic performance has been the least impressive in 
Western Europe, perhaps in all Europe.' The ESRI's overall view was that Irish economic performance had been appalling during the early 1980s. A total of 254,526 people were without work by 1987 (Daly 1994: 122). Ireland had reached the unenviable position of topping Europe's unemployment league. ${ }^{8}$

The Central Bank regarded the economy with pessimism. Its quarterly economic reports foresaw no prospects for immediate improvement in either growth or employment. ${ }^{9}$ More worryingly, it argued that the economic situation did not permit for increases in welfare benefits to needy members of society. ${ }^{10}$ Consequently, the increasing level of poverty, resulting from the depression, was eroding the lives of a growing segment of the population. ${ }^{11}$

According to the OECD (1987: 11-15) between 1979 and 1987 Irish economic performance had been dire: slow growth, rapidly deteriorating public finances, stagnation of per capita disposable income, huge balance of payments deficits, industrial relations turmoil, and a large decrease in domestic demand. As the OECD (1987: 77) put it: 'by the mid-1980s a number of acute imbalances confronted the Irish economy.'

These imbalances were making the business community extremely worried. Leading businessman Tony O'Reilly warned of the dangers of IMF involvement, and the loss of economic sovereignty. ${ }^{12}$ Taoiseach FitzGerald stated that 'the national debt, and interest payments, were rising faster than national income, and constituted a vicious circle. ${ }^{, 13}$ The leader of the opposition, Charles Haughey, remarked that 'the economy is at a total stand-still. ${ }^{14}$ Amongst the public consensus held that the country was in the midst of a serious financial crisis. ${ }^{15}$ Thus, 'by 1987 the Irish economy was universally seen to have reached nadir. 16

\section{Sweden 1990-1992}

Although prosperity returned to Sweden during the 1980s, by the 1990s, the country was experiencing economic malaise. Increasingly, the size of the public sector was seen as a principal factor in the country's stagnation. Public sector employment, which had accounted for about one fifth of total employment in the 1960s came to constitute over 35 per cent of all employment in Sweden by the end of the 1980s (Olsson, 1990: 124). Public expenditure rose from 30 per cent of GDP in 1960, to over 60 per cent by the late 1980s, making it the largest public sector in the world. ${ }^{17}$ Attempts to maintain industrial competitiveness, an enormous public sector, and full employment, resulted in rising inflation. $^{18}$

Inflation surpassed 10 per cent in 1990. The Bank of International Settlement (BIS) observed that Sweden's 10.5 per cent inflation rate was the worst of the ten leading industrialised countries. ${ }^{19}$ This failure to sustain non-inflationary growth resulted from a sluggish productivity growth. As can be seen in Figure 5, interest rates peaked at 14 per cent in 1992, while unemployment stood at 6 per cent. This was considered an extraordinary high level of unemployment in a country accustomed to levels below what is regarded the natural rate of unemployment.

\section{FIGURE 5 HERE}

When we examine indicators of economic performance we are confronted with a scene of stagnation. GDP growth, after recovering from the setbacks of the early 1980s, fell 
dramatically by the end of that decade. By the early 1990s the rate of GDP growth, and GDP per capita growth, were actually shrinking. At the same time GNI per capita was declining. Figure 6 clearly highlights the decline of the Swedish economy, with the measure for averaged GDP growth a clear indicator of the overall poor performance.

\section{FIGURE 6 HERE}

Whereas the debt/GDP ratio had been falling throughout the early 1980s, it started to rise from 1988 onwards, almost doubling in six years. Between 1990 and 1992 Sweden's debt/GAP ratio jumped by 34 per cent, and enormous increase in such a short time. At the same time, Swedish trade openness, although dropping somewhat at the start of the 1990s, recovered lost ground quickly, and by 1993 stood above 60 percent. This was a similar level to what it had been five years earlier, although it was still far below the 1984 high of almost 68 per cent. The decline and recover of imports and exports was similar to overall recover of trade openness in the early 1990s. Thus, despite the above figures pointing to slowing growth, the level of activity in economy was on the rebound by 1992 .

\section{FIGURE 7 HERE}

From Figure 8 below we can see that there was a high level of volatility in FDI inflows to the economy throughout the 1980s. But, what is clear is that the depths of the toughs were no match for the heights of the peaks. Consequently, the level of FDI inflows increased throughout the period when seen as a whole. We can also see that by the early 1990s there was a decline in the level of FDI inward stock, and that gross capital formation was slowing somewhat. Nevertheless, inward FDI stock, as a percentage of GDP, was rising gradually, having remained above 5 per cent during the early 1990s.

\section{FIGURE 8 HERE}

By 1991 the domestic and international media, national commentators, domestic and international organisations, and the central bank, were pointing out that the economy was in trouble. Unemployment increased under the impact of the government's austerity measures. $^{20}$ The following year saw unemployment at 5.3 per cent, a post war peak. There was general fiscal instability, with the current budget deficit, public sector borrowing requirement, and national debt, rising rapidly. The BIS observed that 'although inflation had been rising since 1986 in the ten leading industrialised countries Sweden had displayed the worst performance. ${ }^{21}$ Economic growth, well below the OECD average of 3.5 per cent (Delsen and van Veen, 1992: 94), went into reverse in 1991. ${ }^{22}$ The Washington Post argued that the people of Sweden were becoming increasingly troubled by the country's slow growth, and doubted their ability to maintain the standard of living they were accustomed to. ${ }^{23}$ The Guardian pointed out that 'this was the first time the economy has contracted since 1942. ${ }^{24}$ For the Investors Chronicle recession, rising unemployment, and a soaring budget deficit indicate the embattled state of the economy. ${ }^{25}$ According to Aftonbladet, an unemployment rate of over 3 per cent, while low in comparison to other European countries, was regarded as sky-high in Sweden. $^{26}$ Svenska Dagbladet pointed out that new policies were needed to fix the 
economy. ${ }^{27}$ The Herald Sun argued that while Swedish companies invested only 10 per cent of their resources abroad in the early 1980s, this figure expanded to 75 per cent by the 1990s. ${ }^{28}$ The reason for this, according to Ulf Jakobsson, chief economist at Svenska Handsbanken, was that entrepreneurs faced so many taxes it was difficult to achieve a positive rate of return. ${ }^{29}$

By 1991 most economists argued that the economy was in difficulty. "Sweden is in a very severe recession. There is a crisis in every major part of the public sector health, education, childcare, and aged care," said Anders Aslund, the country's leading economist. $^{30}$ The OECD (1992: 29) pointed out that those in training programmes were not counted as unemployed even though they had no jobs. "Sometimes these programmes just tie people up and have the effect of keeping them away from real jobs," observed economist Gunnar Eliasson. ${ }^{31}$

The OECD (1990: 11) argued that during the late 1980s Sweden's economy had overheated. However, this problem remained unresolved prior to 1989 (OECD, 1990: 27). Swedish export performance was weak (OECD, 1990: 18). Sweden had the largest budget surplus in the OECD in 1989, but the largest deficit by 1993 (OECD, 1994: 9). According to the OECD (1994: 11) 'the current recession is unique in depth when measured by trend deviations of either output or employment.' The OECD (1992: 99) was concerned that Swedish economic dynamism had suffered due to a lack of competition in the public sector and in parts of the private sector. This reduced incentives to improve business efficiency. Yet, despite all the negative opinions, by October 1991 The Financial Times was arguing that the economy had reached the bottom of its recession. ${ }^{32}$

\section{TABLE 1 HERE}

From Table 1 it is clear that Ireland (1986-1987), satisfies most of the observable implications. Consequently, we argue that Ireland experienced a macroeconomic crisis in the period 1986-1987. However, Sweden 1990-1992 satisfied just over half, but less than two thirds, of the 17 observable implications. According to the Hogan and Doyle (2007; 2008) framework Sweden 1990-1992 does not constitute a macroeconomic crisis.

The next section examines both periods for ideational change, and if there was ideational change, did policy change followed? If the central hypothesis of what constitutes a critical juncture is to hold, we would expect to possibly identify ideational and policy change in Ireland (1986-1987), but not in Sweden (1990-1992). This is because the latter did not experience a macroeconomic crisis, and the occurrence of such a crisis is integral to Hogan and Doyle's (2007: 2008) critical juncture hypothesis and framework - constituting its first stage.

\section{Section 5: The Identification of Ideational and Policy Change}

\section{Ireland 1986-1987}

The Fine Gael/Labour coalition government experienced considerable difficulty devising an effective strategy to deal with the growing economic crisis (O'Byrnes, 1986). 'An attempt to achieve fiscal correction and disinflation through increased taxation rather than expenditure reduction, completed the grim economic picture' (McCarthy, 1999: 5). The 
coalition's handling of the economic crisis generated dissent and dissatisfaction with the mode of economic governance employed. The business community was alarmed, with leading businessman, Michael Smurfit, observing that the continual delay in tackling the underlying economic problems would only make the cure more difficult to implement. ${ }^{33}$ Tony O'Reilly warned 'bitter' and 'hard' decisions would have to be taken to right the economy. ${ }^{34}$

The coalition government's policy of distancing the trade unions from policy making ensured they remained fractious and critical (Collins, 1993; Wickham, 1992). The OECD, and the national media, were highly critical of the government. ${ }^{35}$ The Irish Independent observed that the coalition government had been disastrous. ${ }^{36}$ Opposition leader Charles Haughey (1986) denounced the policies of the coalition government, and supported union leaders' calls for a return to social partnership agreements. A step in this direction was taken when the Fianna Fáil began meeting with the unions.

The problems with the economy, and extant policy's inability to right the situation, produced a window of opportunity for alternative policy ideas to gain support. Eventually, various critiques coalesced into a constructive debate designed to generate new ideas to deal with the crisis. Despite being institutionally embedded, the reigning economic orthodoxy, and all this entailed, including avoidance of corporatism, collapsed as agents agreed collectively that it was inadequate and should be replaced.

In the context of economic despair the government sought to build support among the economic and social interests for a national recovery strategy. Through the involvement of major economic interests and government representatives, the National Economic and Social Council (NESC) became the forum for the generation of new ideas. In autumn 1986 the NESC produced A Strategy for Development, 1986-1990. This predicted existing policies would lead to further emigration, deterioration of the public finances, and reduced flexibility for policy makers. The report emphasized the necessity of a national plan to tackle the public expenditure crisis. It laid out a comprehensive set of alternative economic ideas to replace extant arrangements, making the NESC the primary policy entrepreneur.

At the time politicians of all political hues were coming to realize that something radical had to be done to improve the situation. Prime Minister Garrett FitzGerald acknowledged that 'the national debt and interest payments were rising faster than national income, and constituted a vicious circle. ${ }^{37}$ He regarded the debt burden as a set of handcuffs binding the country with high taxes and interest rates. ${ }^{38}$

Eventually, agents began coalescing around the ideas propagated by the NESC. These included an integrated economic policy focused on stabilising and then reducing the debt-GNP ratio; reform of the tax structure; promotion of the traded structure; and the removal of social inequalities (NESC, 1986: 306). While still in opposition Fianna Fáil sought to build upon the NESC's consensus, and inject the ideas underlying it into the policy domain. To this end Fianna Fail sought to bring the peak trade union and employer organisations back into the policy making process, from which they had been excluded by the collation government. Fianna Fáil embraced the new ideology of restraint and consensus, its leadership adopting the role of a political entrepreneur. The general election of February 1987 saw all political leaders making the case for fiscal rectitude ${ }^{39}$ with Haughey stressing economic recovery as the primary issue. ${ }^{40}$ 
Fianna Fail fought the 1987 election on a platform opposing the Fine Gael-Labour model of economic management, stressing the need for economic recovery. ${ }^{41}$ Opinion polls prior to the election found unemployment the major issue for the electorate, followed by taxation, prices, and finance, indicating that the public were generally dissatisfied with the current situation. ${ }^{42}$ Most importantly, the method and approach set out in A Strategy for Development was absorbed into Fianna Fáil's election manifesto (Breen et al., 1990: 220). Fianna Fail won the election, carrying with it a new set of economic ideas. Thus, with agents in agreement on a new set of economic ideas to replace the old, a new economic orthodoxy was consolidated. They now had to transform the ideas into meaningful policy.

Prior to the election Haughey remarked that the economic situation was one of extreme difficulty (Trench et al., 1987: 18). He said that people were worried about unemployment and emigration, and that they "wanted someone to take the situation by the scruff of the neck. ${ }^{43}$ As the new Fianna Fáil administration was a minority it was considered likely to want to avoid the electoral risk of implementing severe spending cuts. However, the new administration sought to implement far reaching expenditure reductions. $^{44}$ Following the NESC's recommendations, the authorities set as their budgetary objective a reduction in the debt/GNP ratio. The new government's first budget sought much greater fiscal adjustment than had been achieved in previous years. This constituted a marked shift in policy emphasis, and a determination to reduce the deficit (OECD 1989: 16). Expenditure fell by $£ 250$ million, while tax revenue increased by $£ 117$ million (OECD 1987: 21). The implementation of these measures was helped enormously by the opposition supporting the government in its efforts to fix the economy.

Given the scale of the task Fianna Fáil set itself, it wanted to avoid confrontations. Consequently, the government promoted talks on a national pay agreement in accordance with the principles of the NESC report (Jacobsen 1994: 177). The administration was interested in securing a three-year tripartite agreement throughout the economy (Allen, 1997: 170). 'The Taoiseach invited the unions, and the other social partners, to take part in an effort to spur recovery by means of consensus' (Mjoset 1992: 383). Fianna Fáil supported a centralised pay agreement for its benefits in terms of industrial peace and union commitment to painful spending cuts. ${ }^{45}$ Where the coalition government had opposed any revival of this form of union influence, ${ }^{46}$ Fianna Fáil revealed a preference for defusing, rather than opposing, industrial conflict (Hardiman 1988: 237). Thus, the neo-corporatist agreement, the Program for National Recovery, was born. Subsequent years saw more agreements, all based on a shared understanding of the problems facing the economy and society, and the policies required to address them (NESC 1996: 14). The social partnership shifted Ireland's political economy from a British towards a European mode of consensus policy making.

Economic crisis led to a collapse of confidence in the prevailing economic orthodoxy. Outside influences, and policy entrepreneurs, advocated a replacement set of ideas involving fiscal restraint, tax reforms, and consensual policy formulation. Consolidation of change agents around this new economic orthodoxy was achieved through the political entrepreneurship of the Fianna Fail leadership. The party, once in government, altered the setting, instruments, and hierarchy of goals behind economic policy, to conform with the new ideational orthodoxy, resulting in a third order policy 
change. Thus, we have a macro-economic crisis, ideational change, and a radical change in macro-economic policy, which, according to the overarching hypothesis, constitutes a critical juncture. This policy change was one of the pillars upon with Irish economic recovery was built.

\section{Sweden 1990-1992}

Sweden's economic difficulties in the early 1980s provided a window of opportunity for monetarist ideas. Following the Socialdemokratiska arbetarepartiet's (SAP) election in 1982, a number of agents began coalescing around these ideas. The Svenska Arbetsgivarforening (SAF) created Centre for Business and Policy Studies (SNS), and Timbro, disseminated monetarist ideas, which gained ground, especially among influential economists (Blyth 2002: 214-15). Political and policy entrepreneurs, consisting of the leaderships of the Conservative and Liberal parties, the policy elites outside the original social bargain, the SNS and SAF, began aggressively propagating these ideas (Blyth, 1997: 239).

Meanwhile, the media continued to harangue the SAP government, and its policy failures. The New York Times stated that the economy was stagnant. ${ }^{47}$ The Financial Times pointed out that in 1991, under the impact of weak foreign demand, and losses in competitiveness, Swedish exporters lost ground internationally. ${ }^{48}$ According to Business Week by the autumn of 1991 the Social Democrats were already staging a tactical retreat from the welfare state. ${ }^{49}$ By this time, according to The Economist, Sweden's industrial output was in freefall. ${ }^{50}$ Some of the highest taxes in the world, prohibitive interest rates, and high inflation smothered the once-robust private sector. Consequently, according to the Christian Science Monitor, 'Swedish industry, with no incentive to stay, is now scrambling to set up operations abroad, where the returns are higher. ${ }^{51}$ Most worrying of all for the SAP Dagens Industri observed that many Swedes had discovered that they were social democrats by habit and not conviction. ${ }^{52}$

Once the economy faltered, critiques of the SAP by the media, the opposition, and the OECD, enabled change agents to propose monetarism as an alternative economic paradigm. In an environment of unfulfilled economic expectations, contestation of the existing economic orthodoxy by agents, agreed on its inadequacy and need for replacement, resulted in its collapse. From the mid-1980s onwards the SAF, among others, increasingly called into question the corporatist system (de Geer, 1992: 155-157). The SAF assumed the role of a vigorous policy entrepreneur, mounting intense publicity campaigns to improve the electoral prospects of the Liberal and Conservative parties. The SAF's ideas on privatization, and deregulation, also influenced the SAP government which, to combat the crisis, began incorporating monetarist ideas into policy. In 1990 currency outflows prompted the Riksbank to increase interest rates. ${ }^{53}$ To reduce inflation, the government tightened fiscal policy (OECD, 1992: 11), a significant change in macroeconomic policy for an SAP government that previously prioritised high employment. As the economy depended on tight fiscal and monetary policies this meant keeping inflation at the European level, even at the cost of unemployment, something previously unacceptable. $^{54}$ The January 1991 budget highlighted the consolidation of monetarist ideas, as low inflation became the objective of economic policy (OECD, 1992: 39).

The internationalization of financial markets restricted the ability of the government to pursue economic policies diverging from those of other capitalist states, 
forming a 'cognitive lock' (Blyth, 2002). Policies disapproved of by industrialists (and foreign currency dealers) became increasingly difficult to implement (Marshall, 1996: 9). The SAP's decision to apply for European Community (EC) membership in 1990 was a response to the problem of capital outflow. ${ }^{55}$

The 1991 election saw the opposition parties reach consensus around monetarist ideas, a coherent set of alternative theories to rectify the economy. Polls conducted prior to the election by Svenska Dagbladet suggested majority support for the opposition. ${ }^{56}$ Following the election, Carl Bildt, leader of the Moderate Party, formed a four-party government advocating a switch to monetarism. Svenska Dagbladet called the election result the end of an era, ${ }^{57}$ a sentiment echoed in the Financial Times. ${ }^{58}$ The Guardian stated bluntly that the SAP was defeated because "they have messed up the economy. ${ }^{, 59}$ Bildt summed up the result as "a massive mandate for change.",60 Thus, a range of agents consolidated around a new set of economic ideas to replace those that had collapsed. As the orthodoxy underpinning extant policies was replaced, these polices lost the ideational armour that had protected them from change. Sweden had accepted the idea of an alternative economic paradigm. "We have moved to the right in Sweden,' observed Bjorn von Sydow from the Prime Minister's office, 'for the simple reason that the Social Democrats could no longer match higher spending with higher taxes.',61

The coalition government sought to fundamentally change the economy's structure. To right the economy it slashed the role of the state, ${ }^{62}$ selling its shares in 34 companies, ${ }^{63}$ with a value of SKr250 billion. ${ }^{64}$ The preamble to the law instituting this policy stated that private ownership and free competition were the best foundation for a strong economy (Hadenius, 1997: 151). Carl Bildt's message was that the state should not strive after doing what a free society can better manage. In limiting how far state responsibility should extend, Bildt challenged the conventional wisdom since the 1930s. ${ }^{65}$ According to the OECD (1992: 44) a central element of the new economic programme was reduced taxes, matched to reduced spending, to encourage efficiency. Competitive forces were given a greater role in allocating resources in the economy (OECD, 1992: 40). The new administration reduced the benefit system, and began abolishing the employee investment funds, ${ }^{66}$ using their resources to support the development of companies (Hadenius, 1997: 153). This change reflected concerns that the expansion of the public sector involved high costs in lost economic dynamism, and had undermined Sweden's growth prospects. In 1992 union representatives were expelled from most commissions, committees, and agencies. In seeking to change Sweden from social democracy to a more free market economy this government achieved more in its first six weeks in office than any pervious non-socialist administration. ${ }^{67}$

Contrary to the framework's overarching hypothesis - as it failed to identify an economic crisis in Sweden - the dominant economic orthodoxy still collapsed. The SAF, acting as a policy entrepreneur, introduced monetarist ideas, around which consensus developed, leading to their consolidation. Following the SAP's electoral defeat, the nonsocialist government, under political entrepreneur Carl Bildt, changed the settings, instruments, and hierarchy of goals behind economic policy - a third order policy change.

\section{TABLE 2 HERE}

TABLE 3 HERE 
According to the framework, in both cases there were third order changes (paradigm shifts) in macro-economic policy. In Ireland (1986-1987) policy change occurred following what the framework identified as a macroeconomic crisis, the collapse of the dominant economic orthodoxy, the introduction of new ideas into the policy arena, and the subsequent consolidation of change agents around these ideas. In Sweden (19901992) third order policy change also occurred in the wake of ideational change. However, Swedish ideational change was not preceded by what the framework rated as macroeconomic crisis. Nevertheless, most experts consider the Swedish economy to be in crisis at that time.

This raises questions as to the sensitivity of the observable implications employed in the framework, and especially those relating macroeconomic crisis. The findings do not show that a quantifiable macro-economic crisis is a necessary precondition for a paradigm shift in macro-economic policy to occur. However, it is clear that the perception of crisis, as opposed to its verifiable identification, can be crucial in influencing the trajectory of policy formulation (Hay, 1999: 322). This fits with Blyth's (2002: 9) argument that agents must diagnose, and impose on others, their notion of a crisis before collective action to resolve uncertainty can be taken. So, employing a universal set of observable implications for identifying macroeconomic crisis, although a commendable effort, is not ideal. Instead, the criteria could be broadened, developed without a set cut off points, and, as a result, more encompassing. Alternatively, the criteria could be structured in a more case specific manner, to take account of actors' path dependent expectations of economic performance. This would ensure that the observables are more nuanced, and sensitive.

Once change agents agreed that the prevailing policy paradigm was inadequate, and consolidated around a new ideational orthodoxy, policy change followed. To paraphrase Hay (1999: 339), actors are unified in a crisis through their discursive construction of crisis. In terms of Hogan and Doyle's (2007; 2008) framework verifiable exogenous shocks are not as important as endogenous actors' perceptions of shocks. Once actors believe there is a crisis extant policy is no longer secure. Economic shocks can only be fully understood in context. Integrating into the concept of critical junctures actors' perceptions of crisis, and their role in the process of ideational change, is pragmatic, emphasising context matters. This fits with the importance of actors' path dependent expectations of economic performance.

The framework shows that ideation change is crucial for macro-economic policy change. Extant ideational orthodoxy protects existing macro-economic policy. However, should ideational collapse occur, then existing macro-economic policy is no longer secure. This constitutes the window of opportunity Kingdon (1995) spoke of for new policy ideas. If change agents, led by a political entrepreneur, consolidate around a new set of economic ideas, the result will be ideational change, and a third order change in macro-economic policy. 'Groups and individuals are not merely spectators as conditions change to favour or penalize them in the political balance of power, but rather strategic actors capable of acting on "openings" provided by shifting contextual conditions' (Thelen and Steinmo, 1992: 17).

However, the framework fails to explain how newly consolidated ideas are transformed into policy change. The case studies can give us an idea of the process, 
through examining the activities of political entrepreneurs in the policy making arena. But, the framework's assumption that once a new idea is consolidated third order policy change will follow automatically is overly simplistic. Although, in the case studies here, as in the case studies conducted by Hogan and Doyle (2007; 2008), ideational change was followed by third order policy change, it is unrealistic to assume that this will always be the way. Surely, the framework must be extended to encompass an understanding of the activities of political entrepreneurs as they champion new ideas in the policy making environment. Factors such as political uncertainly in the wake of extant policy failure during a crisis should be accounted for. In other words, the framework requires another layer of analysis; this to take account of developments at what Polsby (1984) refers to as the threshold between policy invention and adoption. Such a layer would provide better insights into how new ideas become policy, and what order of policy change results.

\section{Conclusion}

This paper sought to test a framework based upon the hypothesis that a critical juncture in macro-economic policy consists of: macro-economic crisis, ideational change, and radical policy change. Of the case studies examined, Ireland (1986-1987) fulfilled all three stages. However, Sweden (1990-1992) experienced radical policy change in the wake of ideational change, but, this ideational change was not preceded by what the framework deemed a macroeconomic crisis. This was despite the fact that most experts, and nearly all of the qualitative (subjective) observables employed within the framework, considered the Swedish economy to have been in crisis at that time. The Swedish case does not so much undermine the framework's central hypothesis, as its employment of supposedly universally applicable observables for identifying macroeconomic crisis, and in particular the specific quantitative (objective) observables selected.

We conclude that setting out standard "universal criteria" that must be met in order for there to be an economic crisis is unhelpful. Subjective criteria and endogenous factors, and therefore context, are as important when examining a potential crisis. Actors' perceptions of a crisis, and more specifically their role in the process of ideational change to deal with that crisis, are key components leading to third order change in macro-economic policy. Established policies, and the protection afforded by their underpinning ideas, having been brought into question by a crisis, and ideational collapse, are liable to be overcome by change agents consolidating around new ideas. For the framework the presence, or absence, of ideational change is crucial in determining if there will be a third order change in macro-economic policy - and consequently a critical juncture. However, this allows for instances where radical policy change occurs in the absence of what this rigid framework would rate as an exogenous shock.

The framework's failure to attempt to explain how new ideas actually become policy is one of its major drawbacks. To assume that new ideas, once consolidated, will automatically result in third order policy change is overly simplistic. The framework should try to encompass an understanding of the activities of political entrepreneurs as they champion new ideas in the policy making environment. This, at least, would permit greater insights into how new ideas become policy, while also allowing for the possibility that first, second, or third order policy changes might occur. 


\section{Word Count: 7,967 \\ Date: 08/07/2008}

\section{Appendix A}

Macroeconomic Crisis Observable Implications

O1. If annual GDP growth (Pei and Adesnik, 2000); GDP growth per capita; and GDP growth averaged over 5 years were stagnant or negative, then the economy may have been in crisis.

O2. If GNI per capita ppp growth was stagnant or negative, then the economy may have been in crisis.

O3. If national debt, as a percentage of GDP, was above 100 per cent, then the economy may have been in crisis.

04. If national debt, as a percentage of GDP, was increasing at above 15 per cent, per annum, then the economy may have been in crisis.

05. If the importation of goods and services; and the level of trade openness declined, then the economy may have been in crisis.

O6. If FDI inflows, and FDI inward stock declined, then the economy may have been in crisis.

O7. If gross capital formation as a percentage of GDP declined, then economy may have been in crisis.

O8. If the annual inflation rate was above 15 per cent (Pei and Adesnik, 2000), then the economy may have been in crisis.

09. If the annual interest rate was above 15 per cent, then the economy may have been in crisis.

O10. If the annual unemployment rate was above 15 per cent, then the economy may have been in crisis.

011. If opinion polls regarded the economic in crisis, then the economy may have been in crisis.

012. If the national/international media regarded the economy in crisis, then the economy may have been in crisis.

O13. If economic and political commentators regarded the economy in crisis, then the economy may have been in crisis.

014. If the central bank regarded the economy in crisis, the economy may have been in crisis.

O15. If both domestic and international organisations (Organisation for Economic Cooperation and Development (OECD)) regarded the economy in crisis, the economy may have been in crisis.

016. If elected representatives regarded the economy in crisis, the economy may have been in crisis. 
017. If government pronouncements on the economy were consistent with a crisis management approach, the economy

may have been in crisis.

\section{Appendix B}

Idea Generation Observable Implications

\section{Ideational Collapse}

O1. The media questions the efficacy of the current model and/or specific policy areas.

O2. Opposition political parties critique the current model and propose alternative ideas - at election time their platform will be built around these alternatives.

O3. Civil society organizations, e.g. labour unions, employer organizations, consumer groups etc. critique the current model, reflecting Hall's (1989: 12) coalition-centred approach.

O4. Widespread public dissatisfaction with the current paradigm, observable through opinion polls, protests etc.

O5. External or international organizations critique the current model and/or actively disseminate alternative ideas.

\section{New Ideational Consolidation}

O6. A clear set of alternative ideas, developed by policy entrepreneurs, are evident.

O7. A clear change agent (political entrepreneur) injecting new ideas into the policy arena is evident.

O8. The Political Entrepreneur combines a mixture of interests to produce consensus around a replacement paradigm

\section{Appendix C \\ Policy Change Observable Implications}

01. If economic policy instrument settings changed (swiftly; for longer than one government's term of office) there may have been a radical change in government economic policy.

O2. If the instruments of economic policy changed (swiftly; for longer than one government's term of office) there may have been a radical change in government economic policy.

03. If the hierarchy of goals behind economic policy changed (swiftly; for longer than one government's term of office) there may have been a radical change in government economic policy.

\footnotetext{
${ }^{1}$ http://www.budget.gov.ie/2002/2001outturn.asp.

${ }^{2}$ The Irish Times, 3 February, 1987, p. 6.
} 
${ }^{3}$ Irish Independent, 4 February, 1987, p. 8.

${ }^{4}$ The Economist, 24-30 January, 1987, pp. 53-55.

${ }^{5}$ ibid., 3-9 October, 1987.

${ }^{6}$ The Irish Times, 12 February, 1987.

${ }^{7}$ Irish Independent, 17 February, 1987.

${ }^{8}$ The Irish Press, 15 February, 1987.

${ }^{9}$ The Central Bank of Ireland, Quarterly Bulletin, Summer 1987, p. 7.

${ }^{10}$ The Irish Times., 2 February, 1987.

${ }^{11}$ ibid., 12 February, 1987.

${ }^{12}$ Irish Independent, 14 February, 1987, p. 8.

${ }^{13}$ The Irish Times, 11 February 1987, p. 10.

${ }^{14}$ ibid., 4 February, 1987.

${ }^{15}$ Irish Independent, 16 February, 1987.

${ }^{16}$ The Economist Intelligence Unit, 'Ireland: Country Profile 1991-92. (1992), p. 6.

${ }^{17}$ The Guardian, 13 September, 1991, p. 5.

${ }^{18}$ The Economist, 21 September, 1991, p. 33.

${ }^{19}$ The Times, 11 June, 1991, p. 4.

${ }^{20}$ Time International, 30 September 1991, Vol. 138, No. 14, p. 21.

${ }^{21}$ The Times, 11 June, 1991, p. 4.

${ }^{22}$ The Economist, 7 September, 1991, p. 38.

${ }^{23}$ Washington Post, 18 September, 1991, p. A18.

${ }^{24}$ The Guardian, 13 September, 1991, p. 5.

${ }^{25}$ Investors Chronicle, 11 October, 1991, p. 68.

${ }^{26}$ Aftonbladet, 13 September, 1991, p. 5.

${ }^{27}$ Svenska Dagbladet, 5 September, 1991, p. 3.

${ }^{28}$ Herald Sun, 14 October, 1991. p. 42.

${ }^{29}$ The Gazette, 21 September, 1991, p. B1.

${ }^{30}$ Christian Science Monitor, 22 October, 1991, p. 3. 
${ }^{31}$ Newsweek, 2 December 1991, p. 64.

${ }^{32}$ The Financial Times, 23 October, 1991, p. v.

${ }^{33}$ The Irish Times, 9 June, 1981, p. 7.

${ }^{34}$ Irish Independent, 14 February, 1987, p. 8.

${ }^{35}$ ibid., 11 February, 1987.

${ }^{36}$ Irish Independent, 11 February, 1987.

${ }^{37}$ The Irish Times, 11 February 1987, p. 10.

${ }^{38}$ ibid., 3 February, 1987.

${ }^{39}$ The Times, 7 February, 1987.

${ }^{40}$ The Irish Times, 2 February, 1987.

${ }^{41}$ ibid., 2 February, 1987.

${ }^{42}$ ibid., 5 February, 1987, p. 8.

${ }^{43}$ Irish Independent, 13 February, 1987.

${ }^{44}$ Financial Times, 1 April, 1987.

${ }^{45}$ The Irish Times, 10 October, 1987.

${ }^{46}$ ibid., 17 October 1987.

${ }^{47}$ The New York Times, 16 September, 1991, p. 1.

${ }^{48}$ Financial Times, 23 October, 1991, p. v.

${ }^{49}$ Business Week, 20 September, 1991, p. 41.

${ }^{50}$ The Economist, 31 August, 1991, p. 83.

${ }^{51}$ Christian Science Monitor, 22 October, 1991, p. 3.

${ }^{52}$ Dagens Industri, 15 September, 1991, p. 1.

${ }^{53}$ Agence France Presse, 6 December, 1991.

${ }^{54}$ Financial Times, 23 October, 1991, p. v.

${ }^{55}$ Christian Science Monitor, 25 October, 1991, p. 1.

${ }^{56}$ Svenska Dagbladet, 14 September 1991, p.2.

${ }^{57}$ Svenska Dagbladet, 16 September 1991, p. 1.

${ }^{58}$ Financial Times, 17 September, 1991, p. 3. 
${ }^{59}$ The Guardian, 13 September, 1991, p. 5.

${ }^{60}$.Financial Times, 17 September, 1991, p. 3.

${ }^{61}$ The Guardian, 13 September, 1991, p. 5.

${ }^{62}$ Investors Chronicle, 11 October, 1991, p. 68.

${ }^{63}$ European Report, 23 October 1991, p. 1.

${ }^{64}$ The Economist, 16 November, 1991, p. 62.

${ }^{65}$ Financial Times, 13 November, 1991,p .2.

${ }^{66}$ The New York Times, 6 October, 1991, p. 11.

${ }^{67}$ Financial Times, 13 November, 1991, p. 2.

\section{References}

Allen, K. (1997) Fianna Fáil and Irish Labour: 1926 to the Present, London: Pluto Press.

Bacon, P., Durkan, J. and Leary, J. (1986) The Irish Economy: Policy and Performance 1976-1986, Dublin: Economic and Social Research Institute.

Berman, S. (1998) The Social Democratic Moment: Ideas and Politics in the Making of Interwar Europe, Cambridge, MA: Harvard University Press.

Blondel, J. (1995) Comparative Government: An Introduction, (2 ${ }^{\text {nd }}$ ed.) New York: Harvester Wheatsheaf.

Blyth, M. (1997) 'Moving the Political Middle: Redefining the Boundaries of State Action', The Political Quarterly 68(3): 217-314. 
Blyth, M. (2002) Great Transformations: Economic Ideas and Institutional Change in the Twentieth Century, Cambridge: Cambridge University Press.

Breen, R., D., Hannan, F., Rottman D. B. and Whelan, C. T. (1990) Understanding Contemporary Ireland: State, Class, and Development in the Republic of Ireland, London: Macmillan.

Capoccia, G. and Kelemen, R. D. (2007) 'The Study of Critical Junctures: Theory, Narrative, and Counterfactuals in Historical Institutionalism', World Politics 59: 341369.

Collier, R. B. and Collier, D. (1991) Shaping the Political Arena: Critical Junctures, the Labour Movement, and Regime Dynamics in Latin America, Princeton, NJ: Princeton University Press.

Collier, D. (1997) 'Comparative Method in the 1990s', APSA-CP: Newsletter of the APSA Organised Section in Comparative Politics 9(1): 1-5.

Collins, S. (1993) Spring and the Labour Story, Dublin: O’Brien Press.

Daly, A. (1994) 'Representing Employers: The Irish Business and Employers' Confederation', in T. V. Murphy and W. K. Roche (eds.) Irish Industrial Relations in 
Practice, Dublin: Oak Tree Press in association with the Graduate School of Business University College Dublin.

De Geer, H. (1992) The Rise and Fall of the Swedish Model, Chichester: Garden Publications.

Delsen, L. and van Veen, T. (1992) 'The Swedish Mode: Relevant for Other European Countries?' British Journal of Industrial Relations 30 (1).

Fearon, J. D. (1991) 'Counterfactuals and Hypothesis Testing in Political Science', World Politics 43: 577-592.

Fearon. J. D. (1996) 'Causes and Counterfactuals in Social Science: Exploring an Analogy Between Cellular Automata and Historical Processes', in P. E. Tetlock and A. Belkin (eds.) Counterfactual Thought Experiments in World Politics, Princeton: Princeton University Press.

Garrett, G. and Lange, P. (1995) 'Internationalization, Institutions, and Political Change', International Organization 49(4): 627-655.

Hadenius, S. (1997) Swedish Politics During the $20^{\text {th }}$ Century - Conflict and Consensus, Stockholm: Svenska Institute. 
Haggard, S. (1988) 'The Institutional Foundations of Hegemony: Explaining the Reciprocal Trade Agreements Act of 1934', International Organization 42(1): 91-119.

Hall, P. A. (1993) 'Policy Paradigms, Social Learning, and the State: The Case of Economic Policy making in Britain', Comparative Politics 25(3): 275-296.

Hardiman, N. (1988) Pay, Politics and Economic Performance in Ireland 1970-1987, Oxford: Clarendon.

Haughey, C. (1986) The Spirit of the Nation: The Speeches and Statements of Charles J. Haughey (1957-1986), Cork: Mercier Press.

Hay, C. (1999) 'Crisis and the Structural Transformation of the State: Interrogating the Process of Change', The British Journal of Politics and International Relations 1(3): $317-344$.

Hogan, J. W. (2005) 'Testing for a Critical Juncture: Change in the ICTU's Influence over Public Policy in 1959', Irish Political Studies 20(3): 23-43.

Hogan, J. W. (2006) 'Remoulding the Critical Junctures Approach', Canadian Journal of Political Science 39(3): 657-679. 
Hogan, J. W. and Doyle, D. (2007) 'The Importance of Ideas: An A Priori Critical Juncture Framework', Canadian Journal of Political Science 40(4): 883-910.

Hogan J. W. and David Doyle, 2008. 'Macroeconomic Policy Change: Ireland in Comparative Perspective,' Irish Political Studies, 23(1): 77 - 97.

Jacobsen, J. K. (1994) Chasing Progress in the Irish Republic, Cambridge: Cambridge University Press.

Kennedy, K. Conniffe, D. (1986) Employment Policy in Ireland, Dublin: Economic and Social Research Institute.

Kingdon, J. (1995) Agendas, Alternatives, and Public Policy, (2nd ed.) New York: Harper.

Leddin, A. J. and Walsh, B. M. (1998) The Macroeconomy of Ireland, (4th ed.) Dublin: Gill \& Macmillan.

Legro, J. W. (2000) 'The Transformation of Policy Ideas', American Journal of Political Science 44(3): 419-432.

Mahler, G. S. (1992) Comparative Politics: An institutional and Cross-national Approach, Englewood Cliffs, NJ: Prentice Hall. 
Mahoney, J. (2000) 'Path Dependence in Historical Sociology', Theory and Society 29(4): 507-548.

Mahoney, J. (2001) 'Path Dependent Explanations of Regime Change: Central America in Comparative Perspective', Studies in Comparative International Development 36(1): 111-141.

Mahoney, J. (2003) 'Long-Run Development and the Legacy of Colonialism in Spanish America', American Journal of Sociology 109(1): 50-106.

Marshall, M. (1996) 'The Changing Face of Swedish Corporatism: The Disintegration of Consensus', Journal of Economic Policy 30(3): 843-858.

Mayer, L. C., Burnett, J. H. and Ogden, S. (1993) Comparative Politics: Nations and Theories in a Changing World, Englewood Cliffs, N.J: Prentice Hall.

McCarthy, D. (1999) 'Building a Partnership,' in B. Reynolds and S. Healy (eds.) Social Partnership in a New Century, Dublin: CORI Justice Commission.

Mjoset, L. (1992) The Irish Economy in a Comparative Institutional Perspective, Dublin: NESC, 1992. 
National Economic and Social Council, (1986) A Strategy for Development 1986-1990: Growth, Employment and Fiscal Balance, Dublin: National Economic and

O’Byrnes, S. (1986) Hiding Behind A Face: Fine Gael Under FitzGerald, Dublin: Gill and Macmillan

Olsson, S. (1990) Social Policy and Welfare State in Sweden, Lund: Arvik.

Organisation for Economic Cooperation and Development, (1987) Ireland 1987, Paris: OECD.

Organisation for Economic Cooperation and Development, (1989) Ireland 1989, Paris: OECD.

Organisation for Economic Cooperation and Development, (1990) Sweden 1990, Paris: OECD.

Organisation for Economic Cooperation and Development. (1992) Sweden 1992, Paris: OECD.

Organisation for Economic Cooperation and Development, (1994) Sweden 1994, Paris: OECD. 
Pei, M. and Adesnik, A. D. (2000) 'Why Recessions Don't Start Revolution', Foreign Policy 118: 138-151.

Pierson, P. (1993) 'When Effects Become Cause: Policy Feedback and Political Change', World Politics 45(4): 595-628

Pierson, P. (2000) 'Increasing Returns, Path Dependency, and the Study of Politics', American Political Science Review 94(2): 251-267.

Pierson, P. (2004) Politics in Time: History, Institutions, and Social Analysis, Princeton University Press: Princeton, NJ.

Pierson, P. and Skocpol, T. (2002) 'Historical Institutionalism in Contemporary Political Science', unpublished paper: 1-33.

Polsby, Nelson W. (1984) Political Innovation in America: The Politics of Policy Initiation. New Haven, CT: Yale University Press.

Steinmo, S. (1989) 'Political Institutions and Tax Policy in the United States, Sweden, and Britain,' World Politics 41(4): 500-535. 
Streeck, W. and Thelen, K. (2005) 'Introduction: Institutional Change in Advanced Political Economies', in K. Thelen and W. Steeck (eds.) Beyond Continuity. Institutional Change in Advanced Political Economies, Oxford: Oxford University Press.

Thelen, K. and Steinmo, S. (1992) 'Historical Institutionalism in Comparative Politics', in S. Steinmo, K. Thelen, and F. Longstreth (eds.) Structuring Politics: Historical Institutionalism in Comparative Analysis, Cambridge: Cambridge University Press.

Thelen, K. (1999) 'Historical Institutionalism in Comparative Politics', Annual Review of Political Science 2: 369-404.

Thelen, K. (2004) How Institutions Evolve: The Political Economy of Skills in Germany, Britain, the United States and Japan, Cambridge: Cambridge University Press.

Trench, B., Barry, G., Browne, V., O’Toole, F. and Whelan, S. (1987) Magill Book of Irish Politics: February'87, Dublin: Magill.

Wickham, J. (1992) 'Industrialisation, Work and Unemployment in Ireland: A Sociological Profile,' in P. Clancy, S. Drudy, K. Lynch, and L. O'Dowd (eds.) Ireland: A Sociological Profile, ( $4^{\text {th }}$ ed.) Dublin: Institute of Public Administration in association with the Sociological Association of Ireland. 


\section{Figures and Tables}

Figure 1: Interest/Inflation/Unemployment Rates

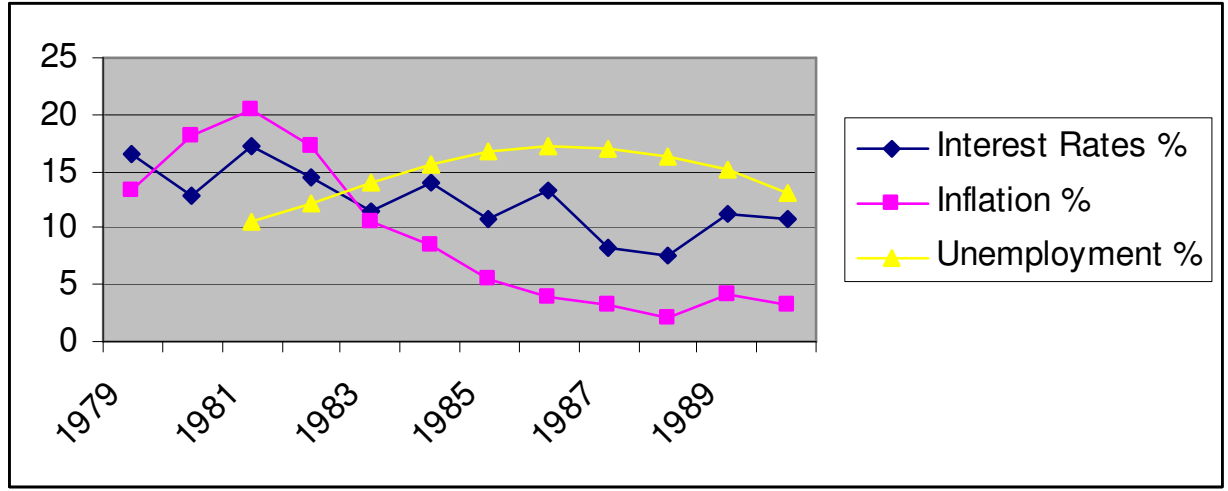

Source: Data Gob, Government Indicators Database

Figure 2: Growth Measures

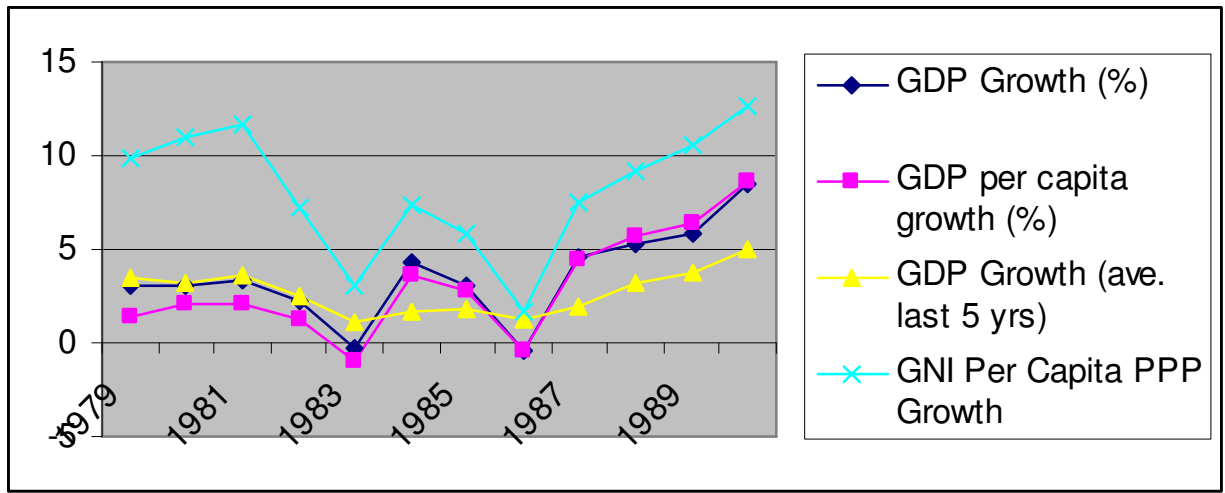

Source: Data Gob, Government Indicators Database 
Figure 3: Debt and Economic Openness

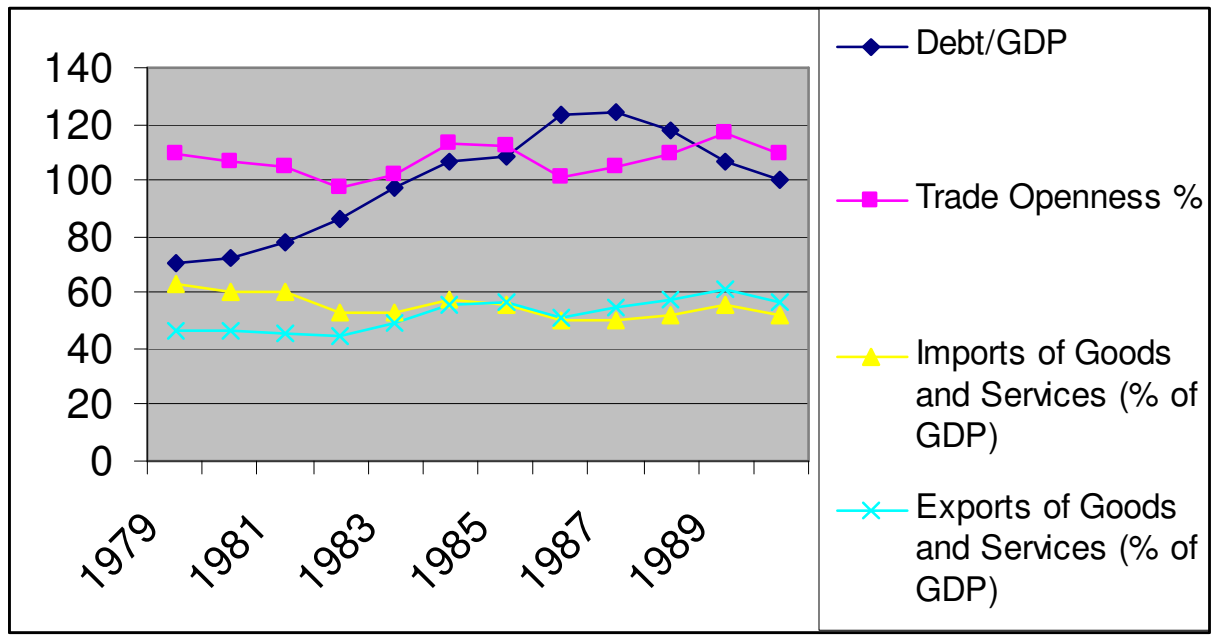

Source: Data Gob, Government Indicators Database

Figure 4: FDI and Gross Capital Formation

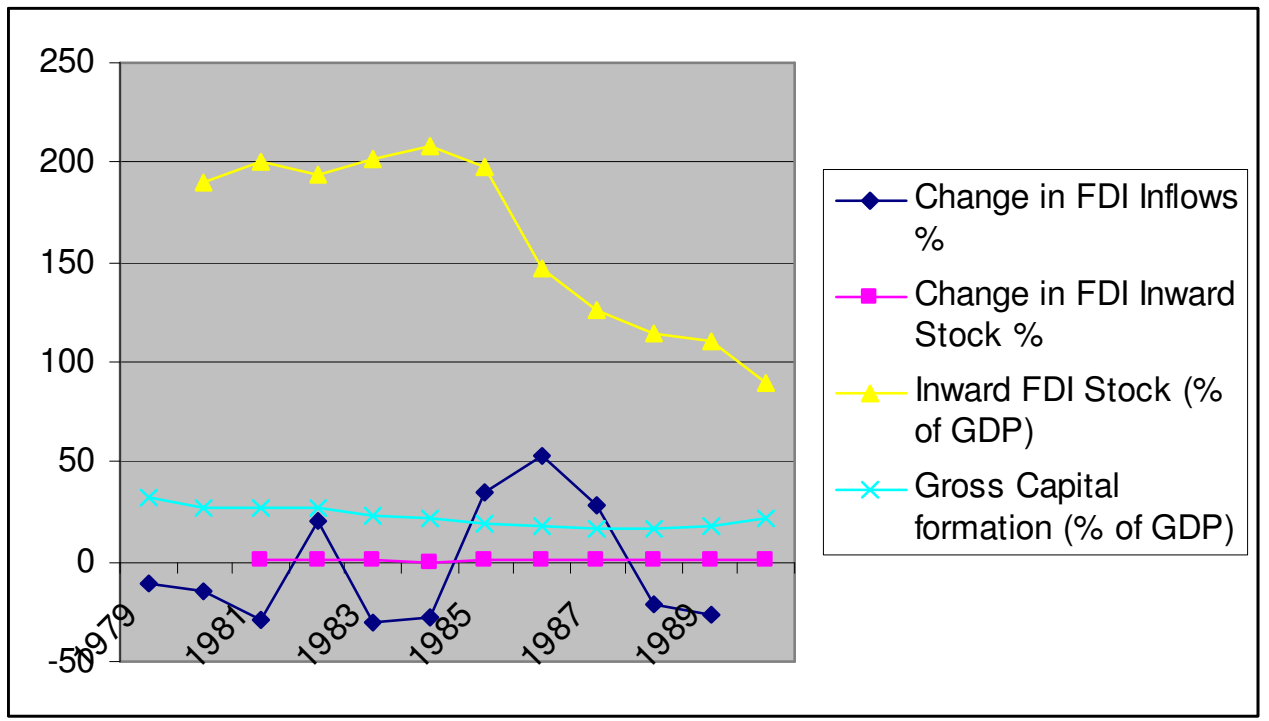

Source: Data Gob, Government Indicators Database

Figure 5: Interest/Inflation/Unemployment Rates 


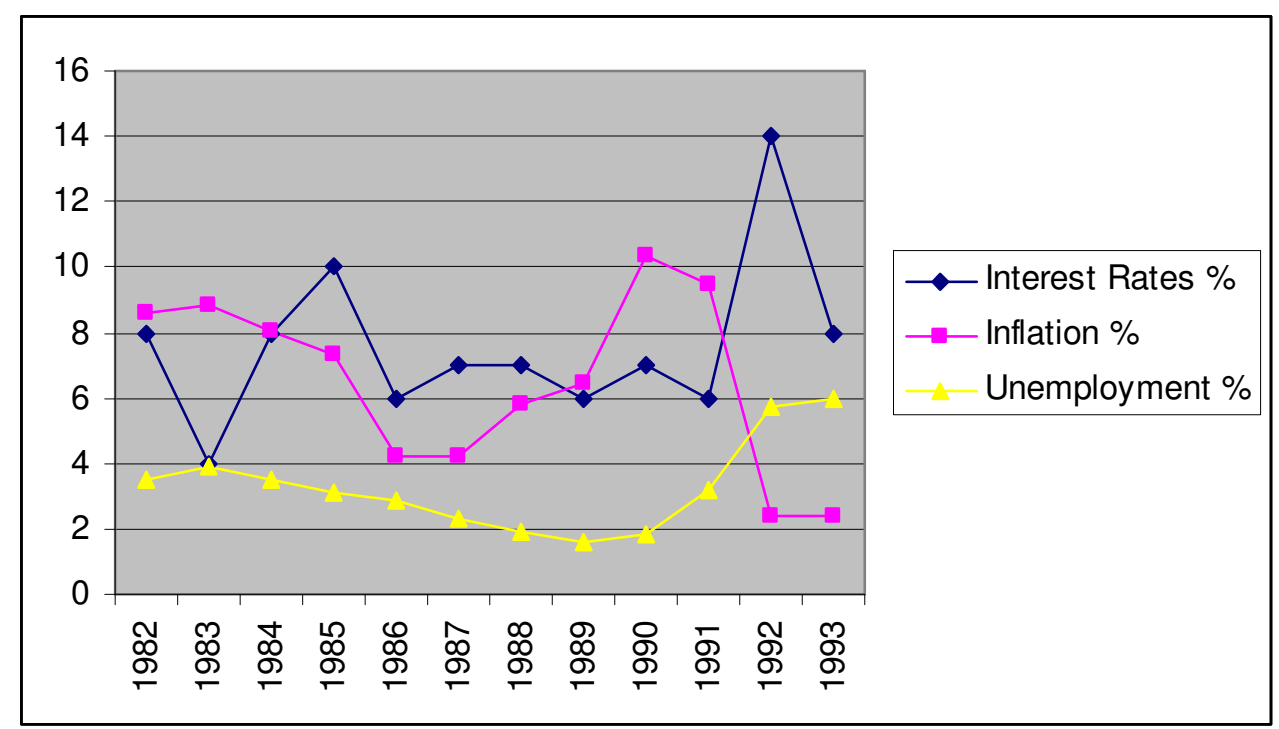

Source: Data Gob, Government Indicators Database

Figure 6: Growth Measures

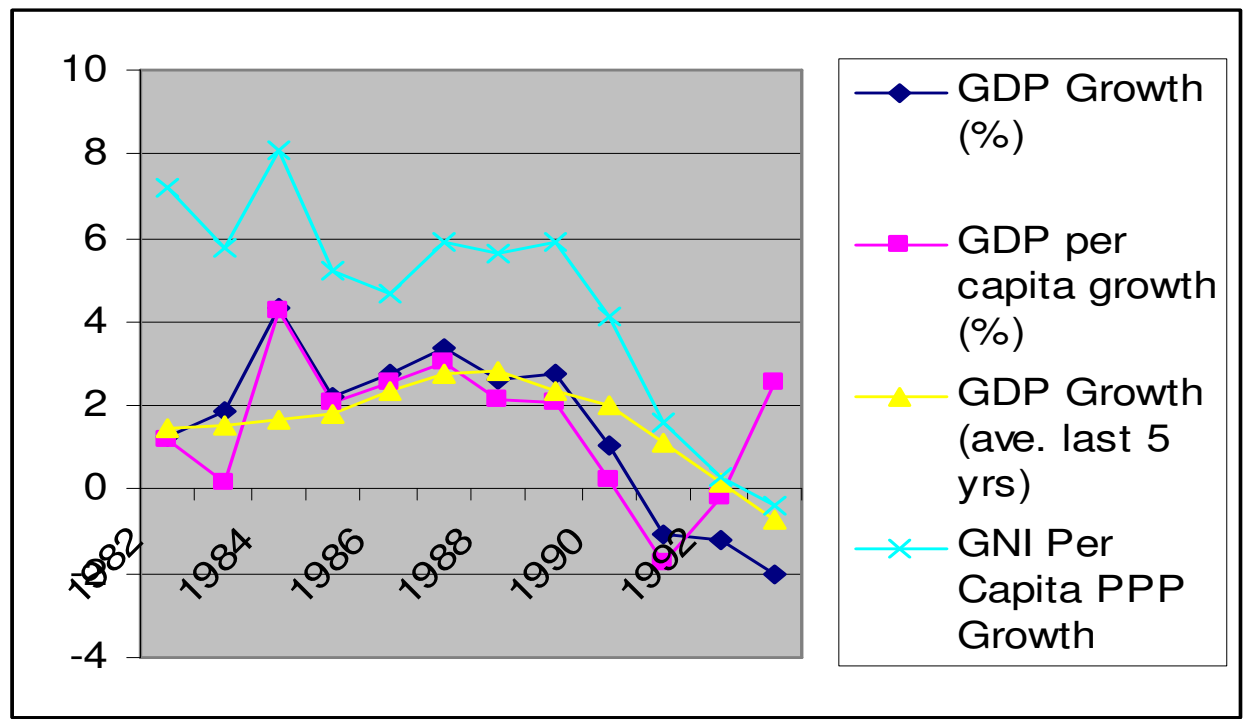

Source: Data Gob, Government Indicators Database

Figure 7: Debt and Economic Openness 


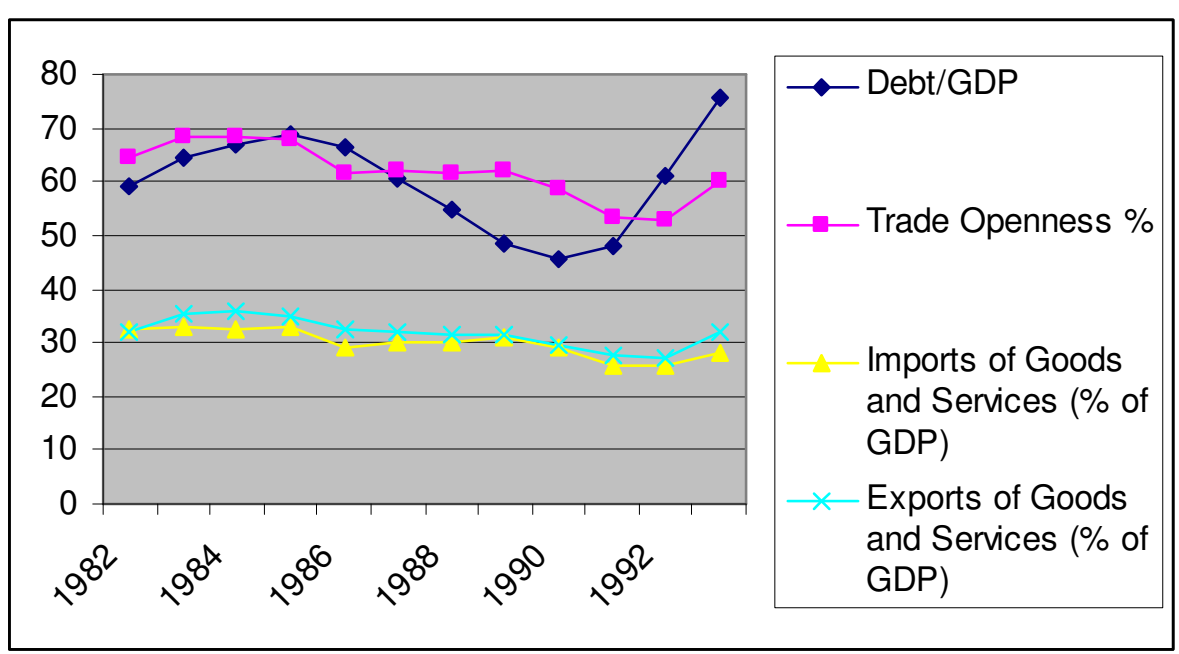

Source: Data Gob, Government Indicators Database

Figure 8: FDI and Gross Capital Formation

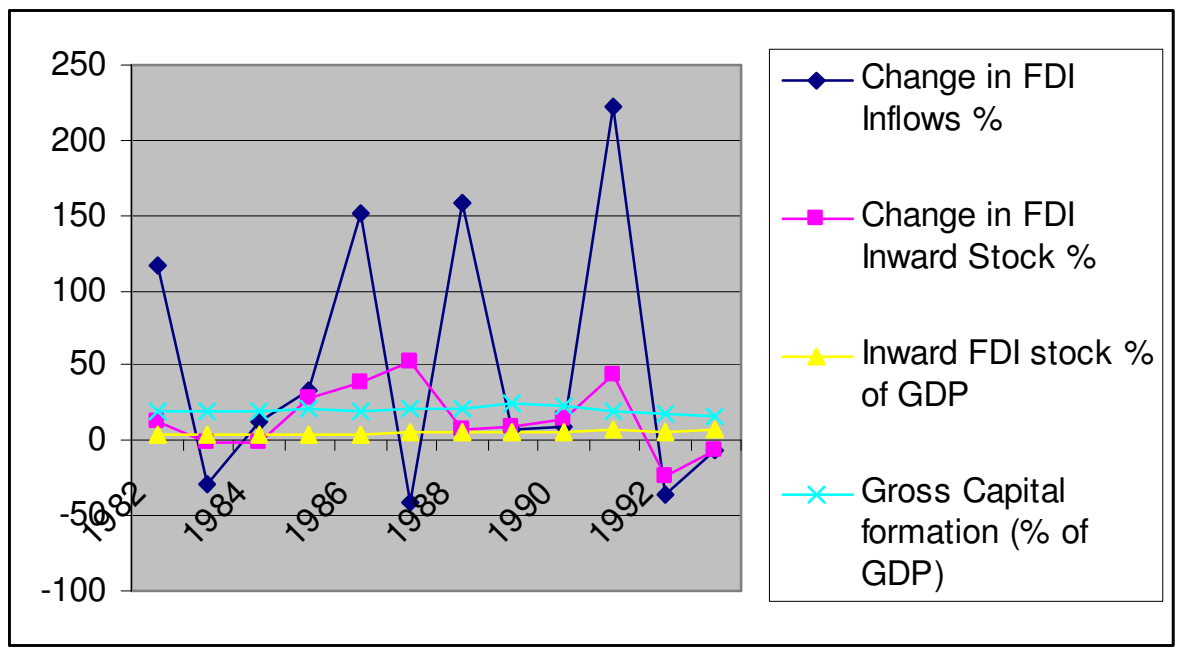

Source: Data Gob, Government Indicators Database

Table 1 - The Identification of Macroeconomic Crisis

\begin{tabular}{|l|c|c|}
\hline Observable Implications & $\begin{array}{c}\text { Ireland } \\
\text { O1. Main GDP indicators stagnant/negative? }\end{array}$ & $\begin{array}{c}\text { Sweden } \\
1990-1992\end{array}$ \\
O2. GNI per capita PPP growth stagnant/negative? & $\mathrm{X}$ & $\mathrm{X}$ \\
O3. National debt above 100\% of GDP & $\mathrm{X}$ & $\mathrm{X}$ \\
O4. National debt/GDP rising at +15\% per annum? & & $\mathrm{X}$ \\
O5. Importations and trade openness declined? & $\mathrm{X}$ & \\
O6. FDI inflows, and FDI inward stock decline? & $\mathrm{X}$ & \\
O7. Gross capital formation as \% of GDP declined? & $\mathrm{X}$ & \\
O8. Annual inflation greater than 15\%? & & \\
O9. Annual interest greater than 15\%? & $\mathrm{X}$ & \\
O10. Annual unemployment greater than 15\%? & $\mathrm{X}$ & \\
O11. Opinion polls regard the economy in crisis? & $\mathrm{X}$ & $\mathrm{X}$ \\
O12. Media regard economy in crisis? & $\mathrm{X}$ & $\mathrm{X}$ \\
O13. Commentators regard economy in crisis? & &
\end{tabular}




\begin{tabular}{|c|c|c|}
\hline O14. Central bank regard economy in crisis? & $\mathrm{X}$ & \\
\hline $\begin{array}{l}\text { O15. Domestic/international orgs regard economy in } \\
\text { crisis? }\end{array}$ & $\mathrm{X}$ & $\mathrm{X}$ \\
\hline O16. Politicians regard economy in crisis? & $\mathrm{X}$ & $\mathrm{X}$ \\
\hline $\begin{array}{l}\text { O17. Gov. pronouncements on economy consistent } \\
\text { with crisis management approach? }\end{array}$ & $\mathrm{X}$ & $\mathrm{X}$ \\
\hline Economic Crisis & $\mathbf{Y}$ & $\mathbf{N}$ \\
\hline
\end{tabular}

Table 2 - The Identification of Ideational Change

\begin{tabular}{|l|c|c|}
\hline Observable Implications & $\begin{array}{c}\text { Ireland } \\
\text { 1986-1987 }\end{array}$ & $\begin{array}{c}\text { Sweden } \\
1990-1992\end{array}$ \\
\hline $\begin{array}{l}\text { Extant Ideational Collapse } \\
\begin{array}{l}\text { O1. Media questions efficacy of current economic model and/or } \\
\text { specific policy areas. }\end{array}\end{array}$ & $\mathrm{X}$ \\
$\begin{array}{l}\text { O2. Opposition parties critique current model and propose } \\
\text { alternative economic ideas - at elections their platforms are built } \\
\text { around these ideas. }\end{array}$ & $\mathrm{X}$ & $\mathrm{X}$ \\
$\begin{array}{l}\text { O3. Civil society organisations critique current model, reflecting } \\
\text { Hall's coalition-centred approach. }\end{array}$ & $\mathrm{X}$ & $\mathrm{X}$ \\
$\begin{array}{l}\text { O4. Widespread public dissatisfaction with current paradigm, } \\
\text { observable through opinion polls, protests etc. }\end{array}$ & $\mathrm{X}$ & $\mathrm{X}$ \\
$\begin{array}{l}\text { O5. External/international organisations critique current model } \\
\text { and/or actively disseminate alternative economic ideas }\end{array}$ & $\mathrm{X}$ & $\mathrm{X}$ \\
$\begin{array}{l}\text { New Ideational Consolidation } \\
\text { O6. A clear set of alternative economic ideas are evident } \\
\text { O7. A clear change agent (political entrepreneur) to inject new } \\
\text { ideas into the policy arena is evident }\end{array}$ & $\mathrm{X}$ & $\mathrm{X}$ \\
\hline New Ideational Consolidation & Y & Y \\
\hline
\end{tabular}

Table 3 - The Identification of Change in Government Economic Policy

\begin{tabular}{|l|c|c|}
\hline Observable Implications & $\begin{array}{c}\text { Ireland } \\
1986-1987\end{array}$ & $\begin{array}{c}\text { Sweden } \\
1990-1992\end{array}$ \\
\hline $\begin{array}{l}\text { O1. If economic policy instrument settings changed there may } \\
\text { have been a radical change in economic policy. }\end{array}$ & $\mathrm{X}$ & $\mathrm{X}$ \\
$\begin{array}{l}\text { O2. If the instruments of economic policy changed there may } \\
\text { have been radical change in government economic policy. } \\
\text { O3. If the hierarchy of goals behind economic policy changed } \\
\text { there may have been a radical change in government economic } \\
\text { policy. }\end{array}$ & $\mathrm{X}$ & $\mathrm{X}$ \\
\hline Critical Juncture in Macroeconomic Policy & Y & Y \\
\hline
\end{tabular}

